\title{
Dentifrice Powder Dosage Form
}

National Cancer Institute

\section{Source}

National Cancer Institute. Dentifrice Powder Dosage Form. NCI Thesaurus. Code C42908.

A powder composed of a mild abrasives, detergents, flavoring agents, binders, fluoride, and other active and/or inert ing redient(s). 